\title{
現象学的見地からの光の分類 ーフェノメナルな光の工学的条件に関する研究（その1)一
}

THE CLASSIFICATION OF LIGHT BY THE PHENOMENOLOGICAL METHOD

-A study on the factors to produce the phenomenal light (Part 1)-

吉澤 望*, 堀口裕 美**, 平手 小太郎***, 武田 仁**** Nozomu YOSHIZAWA, Hiromi HORIGUCHI, Kotaroh HIRATE and Hitoshi TAKEDA

The aim of this study was to classify the light phenomena that can be optically perceived in the architectural space by applying the mode of appearance of color by D.Katz. We extracted the light phenomena entirely from four documents and tried to classify all of them to these modes.

As a result it became clear that eight modes, excluding surface color, and two modes that is the perception of light and illumination with surface color, are accepted as the classification criteria of 《the phenomenal light $》$.

Keywords : Light, Phenomenal, Mode of appearence, Classification of light.

光、フェノメナル、見えのモード、光の分類

1、序

\section{1 研究の背景と目的}

建築において光が本質的な要素であることは、従来多くの建築家や 研究者によって語られてきたことである。例えば日本の茶室やヨー ロッパのロマネスク・ゴシック期の教会、あるいはル・コルビュジ エやルイス・カーンなど近代の著名な建築家の作品に関して、その 空間内に満ちる独特な光が成り立つ原理を解明しようと、これまで もその建築的手法から精神的効果まで数多くの定性的記述が為され てきている。しかしながらそのような光を定量的あるいは工学的注 1) に解明しようとする試みに関しては、今のところ十分な成果は得ら れていないと言っても良いであろう。

その理由として、一つには光という言葉自体の多義性が障壁となっ て、そもそも何を対象に物理量などとの対応を取ろうとしているの かが曖昧になりがちであることが挙げられる。一言で光と言っても、 空間を照らし出す役割の光、光そのものの知覚をもたらす光、さら には宗教的・象徵的な意味合いでの光など、実に様々な現れ方をす るが、建築における光を定量的に記述していくには、それに先立っ て光のどの部分が定量的に扱いうるのかを予め明確に規定しておく 必要があるだろう。本論文では、建築の言説において光として扱わ
れてきた、視覚的に知覚可能な現象としての光に着目する注 2)。これ は光の作用の結果として現れる建築空間の見えと言ってもよい。 光の現象に着目する理由は、第一に、建築が何よりもまずその空間 体験に根ざしたものであるとすれば、建築における光の言説も全て 実際に知覚された光の現象の上に語られてきたはずだからである。 第二に、知覚可能な現象は、光の心理的印象や精神的効果に比べて、 個人の経験や知識に大きな影響を受けにくく、従って視覚心理学の 知見を基に、より定量的・工学的に光を捉えていくことが可能にな ると考えられるためである。

これまでの光の言説は、光の現象とそれから喚起、連想されるもの とが混在しており、現象のみを捉えて語ることのできる体系が十分 に確立しているとは言い難かったのではないだろうか。近年ス ティーブン・ホールの現象学的と評される光の扱いやジェームズ・夕 レルの光の芸術が注目を集めているが、それらも光にまつわる抽象 的あるいは象徵的な意味合いを一旦そぎ落として、純粋に知覚可能 な光の現象に、見ている人を立ち返らせようとする感がある。光の 現象を捉えることが可能になれば、それを通して光の心理的・精神 的効果などに踏み込んでいく道筋も今以上に整理されていくであろ う。
* 東京理科大学理工学部建築学科 助手 ·博士 (工学)

** 東京大学大学院教育学研究科 博士課程 - 修士 (心理学)

*** 東京大学大学院工学系研究科建築学専攻 助教授. 工博

東京理科大学理工学部建築学科 教授・工博
Assoc. Researcher, Dept. of Arch., Fac. of Sci. and Tech., Tokyo Univ. of Science, Dr. Eng.

Graduate Student, Grad. Sch. of Education, the Univ. of Tokyo, M.A

Assoc. Prof., Dept. of Architecture, Grad. Sch. of Engineering, the Univ. of Tokyo, Dr. Eng.

Prof., Dept. of Arch., Fac. of Sci. and Tech., Tokyo Univ. of Science, Dr. Eng. 
本研究の目的は、最終的には現象としての光の表出の工学的条件を 求めることにあるが、そのためにまず本報（その1）では、現象学 的見地からの建築の光の抽出と分類を行う。

1.2 研究の枠組み : 色の見えのモード (mode of appearance of color) ゲーテは既にその「色彩論」文3) の中で、われわれが知覚するのは 種々の作用であり、光の本質を解明するには、その作用によって生 ずる色の記述を通して行われるべきだと指摘している。光の現象と はまさに光の作用によって生じるものであり、色の現れと深い関係 を持つ。従って本研究では、色に関する現象学的分類といえる、色 の見えのモードの知見をまず導入することにより、建筑における光 の現象の分類を試みた。

色の見えのモードの分類は今世紀初頭カッツなどにより提唱され、 その後 OSA（The Optical Society of America）測色委員会や JIS でも新 しい分類方法が提案された。それぞれの分類は概ね一致するが、OSA および JIS とも、より心理物理的視点が入った分類であり、またいわ ゆる表面色、面色、空間色に力点を置いた定義となっている。従っ て建築的観点から見れば、透明色や鏡映色なども含む、より純粋に 現象学的なカッツの分類の方が、実際の建築的課題と対応付けやす い。また現状ではカッツの「The World of Colour」文1)が最も詳細に 各モードの記述を行っており、今後の分類の下敷きとするには相応 しいと思われる。以上から本研究においては、カッッの提唱した概 念をもとに、光の分類を試みた注3) 注 4)。

\section{3 既往研究と本研究の位置付け}

明田川・鈴木（1983）文6）は、物体が対象として明確に知覚されな い場合光自体として知覚され、かつ物体の知覚には〈明るさ〉〈奥行 き感〉〈大きさと形〉〈テクスチャ〉の 4 属性が関わると指摘した。こ れは知覚可能な現象としての光の定義といった観点から重要である が、本研究ではこれより若干幅広く光を捉えている。また定量的に 光の現象を扱う場合には、より詳細な光の分類のもと、それぞれに 対応した要因の検討が必要になろう。明田川の述べる光自体を扱つ た研究としては鈴木、小泉らによる一連のものがあり、さらに本研 究と同じく、「陰掔礼讃」やヘンリー・プラマーの著作をもとに光の 分類を試みた研究としては、佐藤、古藤、川崎らによる研究がある が、いずれも空間内の光の効果とその要因・しくみを定性的に体系 化したもの文12）13）15)、あるいは光現象のイメージ（心理効果）とそ の要因を扱ったもの文 14) 19) であり、本研究のように現象自体を定量 的に扱おうとする視点とは若干方向性が異なっている。

一方知覚心理学の分野においては、色の見えのモード、特に光源色 （対象が一次光源のように感じられる見え）の現れに関する研究が進 んでおり、例えば池田らによる照明認識視空間の一連の研究文 8)、岡 島らによる研究文 11)、Gilchrist による Anchoring Theory に基づく研究 文2）などが挙げられるが、いずれも建築における光との対応関係は 未整理であり、色の見えのモードと実際の建築における見えとを詳 細に対応付けた研究はまだ為されていない。

\section{2、光の分類}

\section{1 研究素材}

建築における光の現象を抽出するにあたって、表 1 に示す 4 種類の 文献を取り上げた。「陰毉礼讃」文 16) は日本建築の光に関する優れた
著作として広く認められており生 5)、「Light in Japanese Architecture」文 4）(以下「LJA」と略記する）は、古今の日本建築の光を、現象学的 な観点から最も網羅的にかつ定性的に扱った著作として選択した。 「建築行脚」文9) シリーズは建築家の視点を加え、かつ西洋建築の例 を集めるため注 6)、「光の空間」文 18) はより幅広く世界の建築の光を 網羅するために取り上げた。いずれも言葉あるいは写真という媒体 を通して建築の光を扱ったものであり、従って本研究での光の分類 は、全ての空間の直接的体験のもとに行われたものではない。しか しながら光の現象を分類するためには、まず何らかの方法によって その一瞬の現れを切りとる必要があり、そのための媒体として言葉 や写真は最も適切なものであり、さらに既に著明な言説・写真を扱 うことはより客観性を保てることから研究素材として妥当であると 考えた。

表 1. 文献の特徵

\begin{tabular}{|c|c|c|c|c|}
\hline & 文献 & 執筆者 & 対象 & 媒体 \\
\hline (1) & 陰鹥礼讃 & 谷崎潤一郎 & 伝統的日本建築 & 㶻葉 \\
\hline (2) & $\begin{array}{l}\text { Light in Japanese } \\
\text { Architecture }\end{array}$ & \begin{tabular}{|l|} 
Henry \\
Plummer
\end{tabular} & $\begin{array}{l}\text { 伀統的日本建築 } \\
\text { 現代日本建築 } \\
\end{array}$ & 言葉 \\
\hline (3) & 建築行脚 & 磯崎新 & 西洋建筑 & 㗼葉 \\
\hline (4) & 光の空間 & 二川幸夫 & 近現代建築 & 写真 \\
\hline
\end{tabular}

\section{2 光の現象（フェノメナルな光）の分類 : 言葉}

光の現象の抽出手順は以下の通りである。1）文献 (1)〜 (3) から 建築空間や対象物の見えの記述と判断される文章を全て抜き出す。 ただし、対象物の色（例：赤い/白い）・テクスチャ（例：ざらざら した）・素材（例：絧のような）など、いわゆる物体そのものの見え に関する記述はこの段階で選択から除いた注 7)。2）光の印象（例： きれいな光)、光の評価（例 : 好ましい光）、光の精神的効果（例：豊 かな光）、照明器具（例 : 白熱電球の光）、照明手法（例 : トップラ イトによる光）、空間の明暗（例 : 明るい）住 8)、に関する記述を省 く。3）句点で区切られた一文を一個の記述として切り分けた。な お「LJA」は英語・日本語並記であるが原則として英語を参照した注9)。 以上の結果、「陰㹂礼讃」からは 62 個、「LJA」からは 258 個、「建 築行脚」からは 43 個の見えに関わる記述が抽出された。

次に予めカッツの「The World of Colour」から抽出したモードの定 義及び具体例（表 2 の左 3 列分）を参照しながら、各記述を見えの

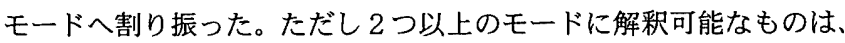
両モードへ重複させて振り分け、一方あるモ一ドへの移行過程と判 断されるものは、その移行対象となるモードへ割り振った注 ${ }^{10) 。 ~}$

以下に各モードの説明と文献ごとの代表事例を挙げていく。各モ一 ドの定義及び具体例、並びにその代表事例（抜粋）と記述の数は表 2 にまとめて示す。

\subsection{1 表面色 (Surface color)}

表面色モードは、観察者との位置関係が明瞭で、堅く突き通せない 見えを持つ。従って空間認識の際に最も重要でかつ基本的なモード と言えよう。物体として知覚される見えとほぼ一致し、知覚心理学 分野で使われる物体色と最も近い概念と考えられる注 11)。

視覚的に見えているものは全て光の作用の結果現れるものであり、 従って光の現象とは、この表面色モードを始め、見えのモード全て を包含するという解釈もありうる。しかしながら本研究での知覚可 
能な現象としての光とは、あくまで建築の言説の中で光として扱わ れてきたものを対象としている。その場合、明田川らが議論してい るように光の現象 (=光自体) は、表面色 (=物体) としての知覚 が薄れたときに生じるものであり、従って一般的な表面色モードは、 現象としての光には含まれないとした方がよい。本論文では、現象 という言葉がもたらす曖昧さを避けるため、以降建築における知覚 可能な現象としての光を《フェノメナルな光》注 12) と再定義し、こ れに一般的な表面色は含まないものとする。

\subsection{2 面色 (Film color)}

面色は、観察者との位置関係が不明瞭で、柔らかで突き抜ける見え を持つ。一様な青空がその分かりやすい例として挙げられる。安定 した空間認識を摇るがせる点で、建築における光の効果の中でも重 要なモードの一つであろう。面色は、障子や乳白色ガラスなどの素 材に現れる例が多いが、これらは後述するように条件によっては 様々なモードへと移りやすい対象である。

•「陰贀礼讃」：書院の障子の白々としたほの明るさについて、「何 か目の前にもやもやとかげろうものがあって、視力を鈍らせている ように感ずる」かつ「明るいけれども少しも眩ゆさの感じられない」 と描写されているが、これらは柔らかく位置関係が不明瞭という面 色の特色が記述されたものといえよう。

建築空間におけるフェノメナルな光としては、完全な面色のみなら ず、面色への移行過程と捉えられる例がむしろ重要で数も多く、こ こではこの移行過程をも光の分類における面色モードに含める。明 田川らの言う《物体の奥行きやテクスチャの知覚が弱まり、対象と して明確に知覚されなくなった時に現れる光自体》も、多くはこの は面色への移行過程の現象と見なすことができよう。なおカッツに よっても表面色から面色への移行 (この場合は Reduction= 還元とい う言葉が当てられいてる)に関しては繰返し言及されており、例えば 表面色および空間色から面色への移行は、逆方向の移行よりも起こ りやすいことが指摘されている。

\「LJA」：安藤忠雄のコンクリート壁に関して「重たいコンクリー トの塊は奇跡的に希薄になって、ほとんど半透明の膜へと変化す る小、また龍安寺の築地塀に関して「溶け出して消え去ってしまわん とするような霞んだ素晴らしい印象を与えることで著名であり、遠 くから見ても近くによっても全体がぼやかされ焦点が合っていない かのよう・・・」記述されているが、表面色としての見えが薄れ、 面色へと移行する過程と捉えられる。

-「LJA」：借景の効果に対して「庭が部分的に輝くような、物質 としてではない光自体の現象」「奥行きを示すものすべてを取り除 き、平板で輝く輪郭だけを切り取りすぐ近くに引き寄せる」などの
記述があるが、枠を通してものを見る行為は、表面色から面色へ還 元する場合の一手法注 13) であり、面色に分類した。

\subsection{3 空間色 (Volume color)}

空間色は、霧のように三次元的に広がり空間を満たしている見えを 持つ。ただし背後に物体を識別できることが必要条件となる。建築 空間が霧状のものに満たされているように見えるという記述は多 く、実際幾つかのヨーロッパの教会の内部空間などにおいて観察す ることが可能であるが、非常に限定された条件のもとに表出する現 象であると思われる。いずれにせよ建築空間を体感する場合の非常 に重要な一要素であると言えよう。

け「陰毉礼讃」：有名な「灯に照らされた蘭」に関して「夜道の闇 などとは何処か違った物質であって、たとえば一と粒と一粒が虹色 のかがやきを持った、細かい灰に似た微粒子が充満しているものの ように見えた」「こういう䦐が狭霧の如く立ちこめていた」「屋内の 『眼に見える䦩』は、何かチラチラとかげろゔものがある」などの記 述があるが、背後の物体の影響をどう捉えるかの判断は難しいが、明 らかに 3 次元の知覚であり、あくまで壁で囲まれた屋内でしか見え ないと限定されていることから、ここでは空間色に分類する。

け「LJA」: 安藤忠雄の本福寺水御堂に関する「赤い光の坩堝となつ た聖域に入ってゆくと、そこは結局煙というよりはなにかもっと練 かく柔らかで、この世のどんな物理的な蒸気とも異なる蒸気が満ち ていたのである」「赤く輝くもやの立ち籠める空間」、あるいは高桐 院の苔庭に関する「一種の濃い金色の光が煙のように存在している のをより強く感ずる」などの記述は空間色の好例として挙げられる。

○「建築行脚」：ル・トロネ修道院に関して「全空間が、微細な光 粒子によって、霧箱のように充填させられた」「光がしぼられ、散光 となり、微粒子状になって、同じくこの内部に充満する」「薄暮のよ うな光の霧のなか」の記述も空間色の例であろう。サン・マルコ寺 院の闃に関しては「閏に包まれていながらも、その奥に堅固に構築 された形式がひそむ」「その表層部を光線がよぎるとき、形式が浮か び上がる」と記述している。磯崎はサン・マルコ寺院の䔵を陰婜礼 讃の闇と同質のものを述べているが、蘭の奥に物体が感知されると いう点で、空間色に含めておくのが妥当と考える住 14)。

\subsection{4 透明面色 (Transparent film color)}

スモークガラス (smoked glass : 現在の ND フィルターと同質なも のを指している）や色ガラスを通して見た場合の見えのモード。. 背 景（=フィルターの向こう側）には必ず表面色が見えている必要が あり、背景の色や明るさには影響を及ぼすが、背景自体をぼかすこ とはない。今回の文献の中では例が非常に少ない。ただし色ガラス の使用は建築においては一般的な手法であり、フェノメナルな光の 一分類として独立させることは問題ないであろ.う。

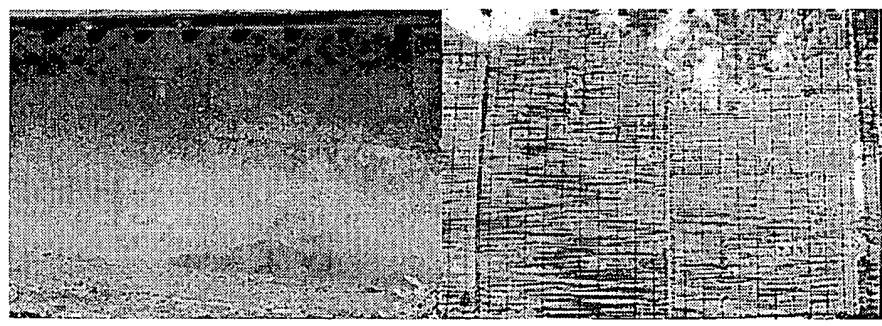

図 1 注 15) 面色: 竜安寺の築地塀
図 2 透明表面色 : 永観堂の策

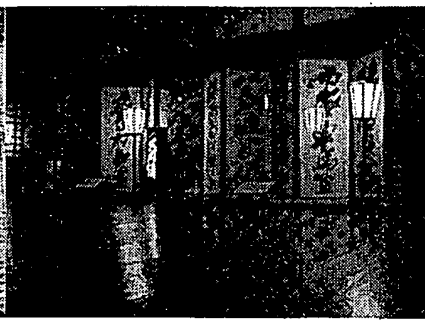

図 3 光沢 : 竜安寺の床

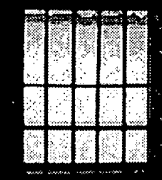

図 4 光輝 : 大徳寺の開口部 
-「LUA」: 伊東豊雄の横浜風の塔に関する「アルミのシリンダー は、投光照明が下から光を投げかけるのに従って、透明からぼんや りに変化する」との記述は、透明面色から後述の透明平面色への変 化の例として挙げられよう。

\subsection{5 透明表面色 (Transparent surface color)}

透明表面色は、ほこりのついたガラスを通して向こうを見る時の見 えのモードで、透明色自体が持つテクスチャが背景に重なる点や、背 景が面色でも表面色でも良い点が透明面色と異なる。すだれや障子 などに代表される半透明の素材の向こう側にものが見える場合、そ の多くが透明表面色と判断されるため、建築空間においては非常に 例が多い。また細かなフレームで分割されたガラスの空面なども、遠 くから見た場合はこのモードになるであろう。

-「LJA」：伊東豊雄のパンチングメタルに関して「この輝く銀の 織物を透視することはできるが、向こう側にあるものはすべて柔ら かく不透明で、蒸気のように織細な布地のようである」、竹の策に関 して「障子より粒状でかすかな刻印を与える」「投影された像は、光 学的な格子を通過し、もやのかかったスケッチとほとんど変わらな い状熊に粉砕され、その像は隙間のまぶしさによってさらに浸食さ れる」などが一例として挙げられる。

\subsection{6 鏡映色 (Mirrored color)}

物体の像が完全に反射されて目に入ってくる場合、つまり鏡に映っ ている場合を、鏡映色モードという。カッツは水銀や黒色のガラス プレートなどを例に挙げている。

-「LJA」: 安藤忠雄のライカ本社ビルの暗いホールに関して「そ の大きなガラス空は黒く細い十字で分割されていて、魔法のように 林に反射しているが、その半分は幻覚である」は鏡映色の例である。

〔建築行脚」:ノーマン・フォスター設計の生命保険会社イプシッ ツに関して「昼間は、その黒カラスが、空の雲や周辺の街並を映す」 も鏡写色と言えよう。

\subsection{7 光沢 (Lustre)}

鏡映色と異なり、光を反射する表面に像が認識できなかったり、表 面構造を部分的に失ったり、本質的に輝いているように見える場合 の見えのモードである。常に表面色の上のみに現れ、その物体より も明るさにおいて勝っている。金属・絧・グラファイト・水の表面 などに現れる。

・「陰贀礼讃」：ガラスや金属のピカピカの光を多少批判的に取り 上げているが、光沢モードの例と言える。

○「LJA」: 苔の庭の見えに関して「太陽は決して直接に地面を照 らすことはないが、木を抜けてこぼれ落ち、ところどころに光る金 色の斑やしみをつくり、それは影が梁く染み込んだ錆ついた古い金 のように見える」、厳島神社の赤に関して「赤い色が最高潮に達し、 いたるところでちらちら光り・.」」など光沢の事例は非常に多い。

\subsection{8 光輝 (Luminosity)}

光が通り抜けているかあるいはそれ自身が発光している印象を持 つモードで、真っ暗な部屋で、半透明の紙や乳白色のガラスに後ろ から照明を当てた場合の見えや、暗閩の中でランタンの明かりを見 たときの、輝く円状の光などをカッツは例として挙げている。面色 との関係が深いが、いわゆる輝きをもつ点でフェノメナルな光とし ては分かりやすくかつ重要である。建築においてはステンドグラス
や障子が輝いている場合は最も一般的な光輝の例であるが、多くの 照明器具そのものも光輝に分類できよう。

○「陰掔礼讃」: 金絵巻に関して「明るい所で一度にぱっとその全 体を見るものではなく、暗いところでいろいろの部分がときどき少 しずつ底光りするのを見るように出来ている」、能役者に関して「皮 虐の色の、内部からぽうっと明かりが射しているような光沢」とい う表現があるが、カッツは明順応の状態では光沢に見えていたもの も、暗い場所で暗順応する状態に移ると、「変わった（weird）」光輝 に見えると指摘しており、上記の例は光輝モードに分類すべきであ ろう。同様に大きな建物の奥の部屋に関して「もう全く外の光が届 かなくなった暗がりの中にある金襖や金屏風が、幾間を隔てた遠い 遠い庭の明かりの穂の先を捉えて、ぽうっと夢のように照り返して いる」も光輝に分類される。

○「LJA」: 障子や下地空に関して、「障子紙の消えかかった薄闇に その光が当たり、墨のような黒で縁取られたまぶしい明かりへと一 瞬のうちに変化するのを見る」、「部屋に薄灯りがともると、下地窓 は抽象的な影を映し出す影絵箱となる。紙は背後から光のあてられ るスクリーンとなって、神秘的な消滅の瞬間をほのめかすイメージ を映し出す」もカッツの定義に近い例と言えよう。

○「建築行脚」：ル・トロネ修道院に関する「幾回かの拡散と反射 を繰りかえした光線は、最後には、石の粗面の粒子間にとどまり、面 が全面的に発光しているような」も発光しているといった点で光輝 に分類できよう。

\subsection{9 妁熱 (Glow)}

光輝と非常に近く区別が難しいが、カッツによれば内部まで色が広 がった感じで、灼熱の方が多少ともはっきりとした輪郭を持つ。焼 かれた鉄の見えが例として挙げられている。

「LJA」：金に関して、「本当の金は物体に固体化した光のいわば縮 図であり・・・光を受け取ると同時にその奥深く内部から光を放っ て輝くものになるのである」は内部から辡いて見えるという点で灼 熱に分類した。また安藤忠雄の光の教会に関する「祭壇の背後には 十字の光によって切られた奥壁があって、何か硬いものをナイフで 切るように刻み取られており、光自身でつくられた燃える十字架が 残されている」は形がはっきりしており、しかも燃えるように光が 溢れていることから、灼熱と見なした。

\section{3 記述の細分類とモードの定義・具体例との対応}

フェノメナルな光の分類項目（カッツの色の見えの分類における モード）と文献から抽出された記述との結びつきの根拠をより明確 に示すために、以下の手続きを行った。1) 各記述をそれぞれのモ一 ドへ割り振った際の、判断の根拠となった籄所を取り出す。ただし それぞれのモード固有の特徴を明確にするため、複数のモードへ割 り振られた記述はここでの作業から予め省いた。2）各記述から抽 出された箇所を類似性に着目して細分類する。3）細分類の内容と カッッの「The World of Colour」から抽出した各モードの定義及び具 体例（表 2）との対応づけを行う。以上の結果を表 3 に示す。

各モードにおける細分類の内容は、必ずしもカッツの挙げた定義・ 具体例のままではなく、若干の類推が必要となるものも多いが、表 3 によりほぼその対応関係が示されたと言えよう。なお透明面色と 鏡映色に関しては、今回選んだ文献においては例が少なく、細分類 
表2. フェノメナルな光の分類：言葉

\begin{tabular}{|c|c|c|c|c|c|}
\hline & Katzによる定義 & Katzによる具体例 & 「陰歌礼䞇」 & [LJA] & 「建築行脚」 \\
\hline $\begin{array}{l}\text { hatip } \\
\text { Surface Color }\end{array}$ & 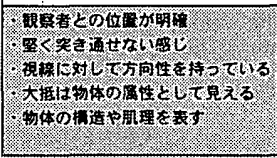 & 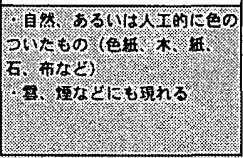 & & & 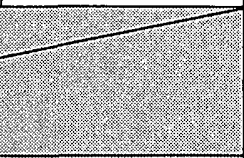 \\
\hline $\begin{array}{c}\text { 面色 } \\
\text { Film Color }\end{array}$ & 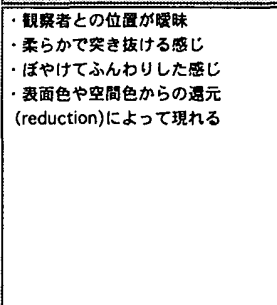 & 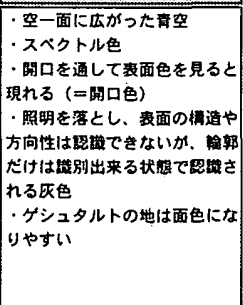 & 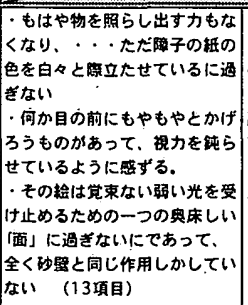 & 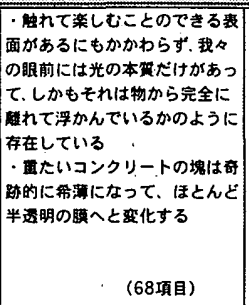 & 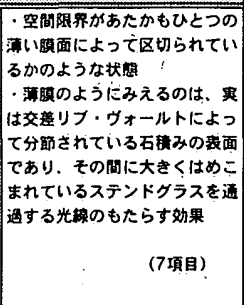 \\
\hline $\begin{array}{c}\text { 空間色 } \\
\text { Volume Color }\end{array}$ & 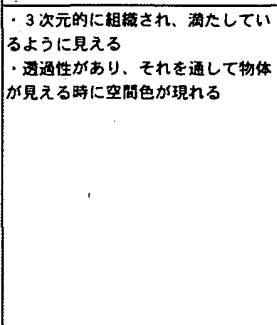 & 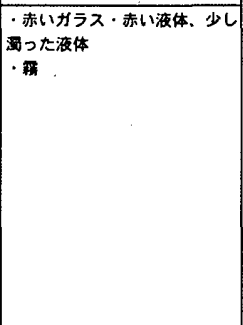 & 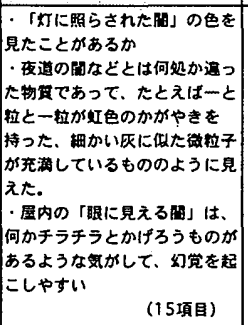 & 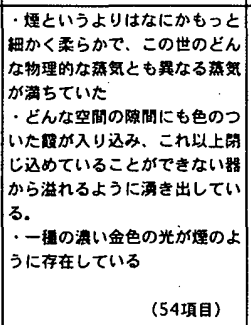 & 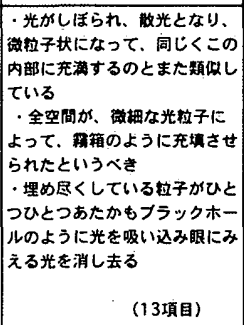 \\
\hline $\begin{array}{c}\text { 透明面色 } \\
\text { Transparent Film } \\
\quad \text { Color }\end{array}$ & 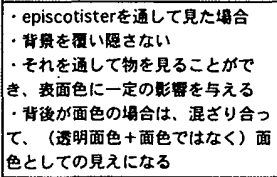 & \begin{tabular}{|l|}
$\cdot$ スモークガラス \\
$\cdot$ 色せラチン \\
$\cdot$ episcotisterによって祦られ \\
る迢明色
\end{tabular} & (O項目) & 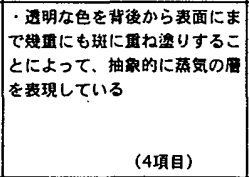 & (O項目) \\
\hline $\begin{array}{c}\text { 透明表面色 } \\
\text { Trasparent Surface } \\
\text { Color }\end{array}$ & 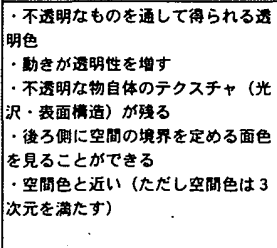 & 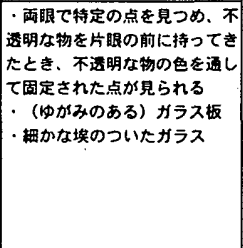 & (0項目) & 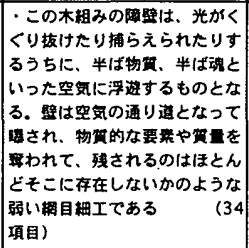 & (O愐目) \\
\hline $\begin{array}{c}\text { 鏡映色 } \\
\text { Mirrored Color }\end{array}$ & 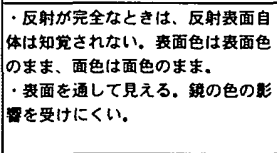 & 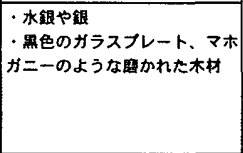 & (O項目) & 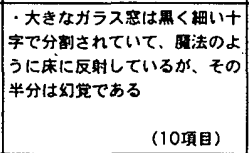 & 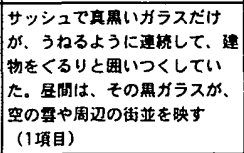 \\
\hline $\begin{array}{l}\text { 光沢 } \\
\text { Lustre }\end{array}$ & 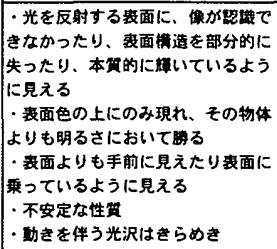 & 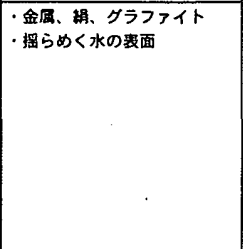 & 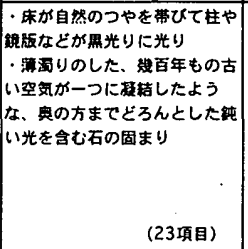 & 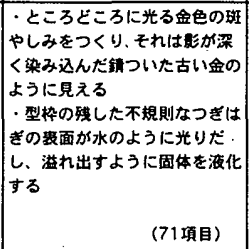 & 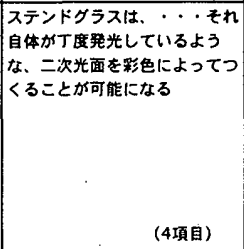 \\
\hline $\begin{array}{c}\text { 光輝 } \\
\text { Luminosity }\end{array}$ & 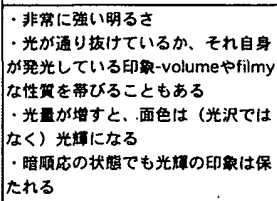 & 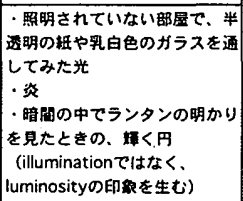 & 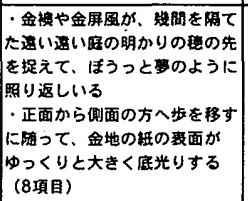 & 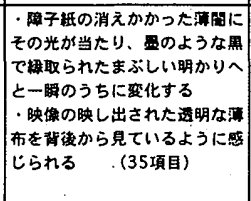 & 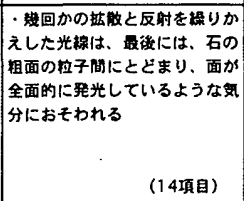 \\
\hline $\begin{array}{l}\text { 灼熱 } \\
\text { Glow }\end{array}$ & 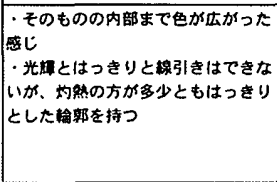 & ·焼かれた铁 & (0項目) & 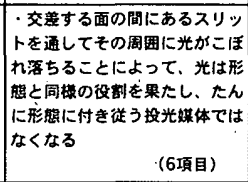 & $\begin{array}{l}\because \\
\text { (O項目) }\end{array}$ \\
\hline $\begin{array}{c}\text { 表面色 } \\
+ \\
\begin{array}{c}\text { ライティング } \\
\text { Lighting }\end{array}\end{array}$ & . & & 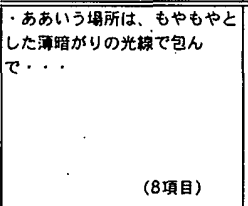 & 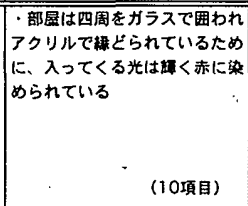 & 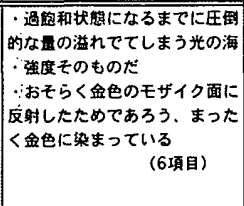 \\
\hline $\begin{array}{c}\text { 表面色 } \\
+ \\
+ \\
\text { イルミネーション } \\
\text { illumination }\end{array}$ & & & & 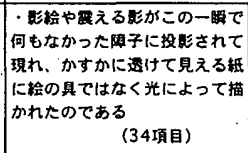 & \\
\hline
\end{tabular}




\begin{tabular}{|c|c|c|c|}
\hline 分類 & 細分類名 & 項目（拢粋） & 対応する定義・具体例（Katz） \\
\hline \multirow{5}{*}{ 面色 } & わずかな見え & 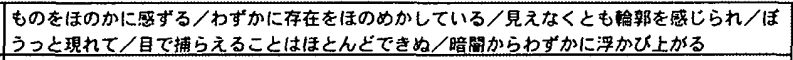 & 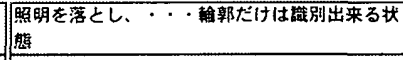 \\
\hline & 物質性の希薄化 & 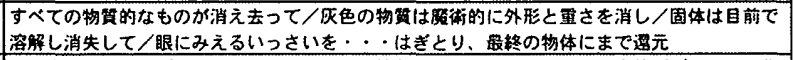 & 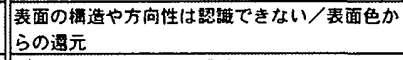 \\
\hline & ほかし & 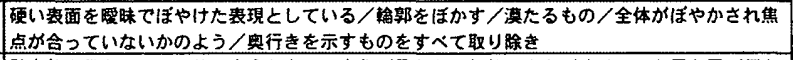 & 㞔やけてふんわりした感し \\
\hline & 気体のような見え & 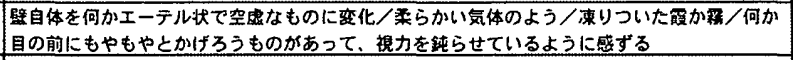 & 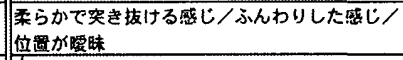 \\
\hline & 明るさ & 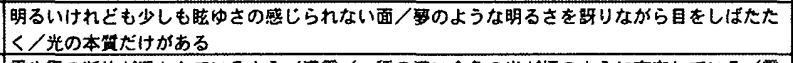 & 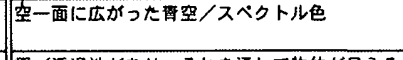 \\
\hline \multirow{4}{*}{ 空間色 } & 露・もや・䗎 & 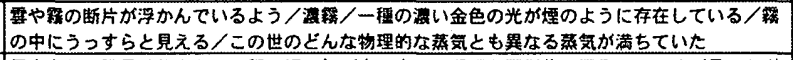 & 策／唀週性があり、それを通して物体が見える \\
\hline & 空間（3次元） & 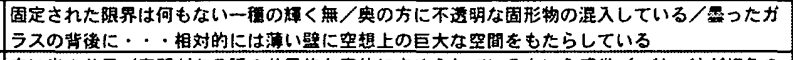 & 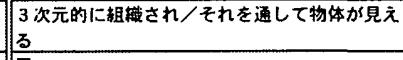 \\
\hline & 粒子 & 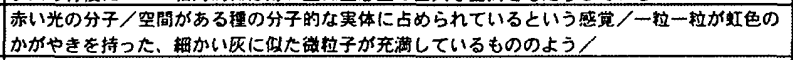 & 䈘 \\
\hline & 光が満ちた & 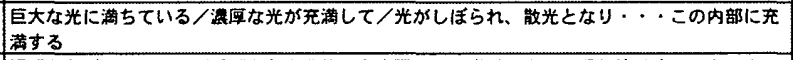 & 满たしているよる \\
\hline 透明面色 & 透明な色 & 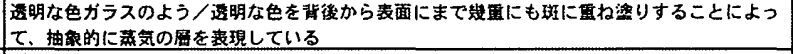 & |色ぜラチン \\
\hline \multirow{4}{*}{ 透明表面色 } & ヴェール・網 & 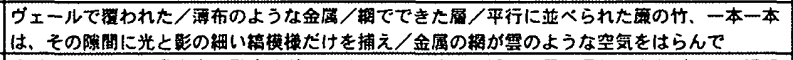 & 監かな埃のついたガラス \\
\hline & かすかに透明 & 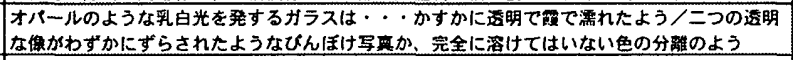 & 不透明なものを通して需られる透明色 \\
\hline & かすかな表面性状 & 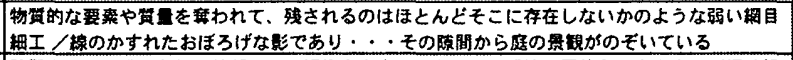 & 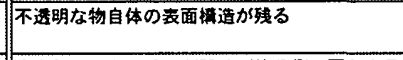 \\
\hline & ほかされた背後の見え & 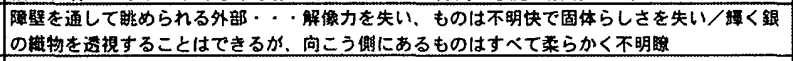 & 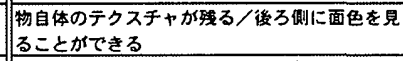 \\
\hline 鏡映色 & 映し出す & 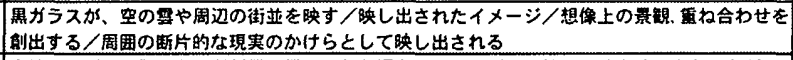 & 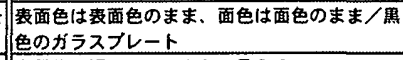 \\
\hline \multirow{5}{*}{ 光沢 } & 輝き & 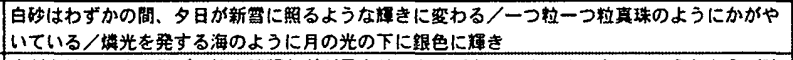 & 本罈的に㛉いているように見える \\
\hline & つや & 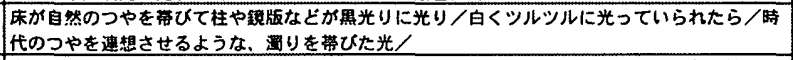 & 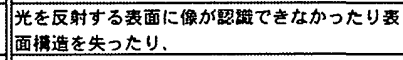 \\
\hline & 金・銀 & 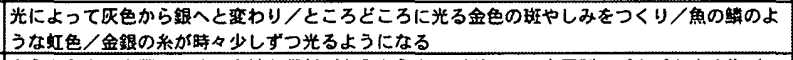 & 金属 \\
\hline & きらきら・びかびか & 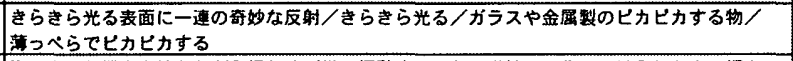 & 動きを伴う光淈はきらめき \\
\hline & 動き & 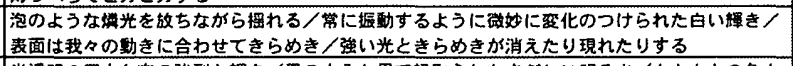 & 但きを伴う光沢はきららめき/不要定な性智 \\
\hline \multirow{5}{*}{ 光輝 } & 光り輝く & 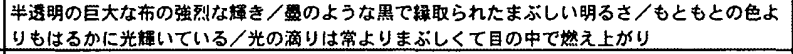 & 非掌に强い明るざてれ自身が哞光している印 \\
\hline & 背後からの光 & 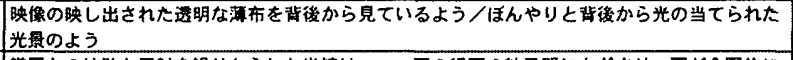 & 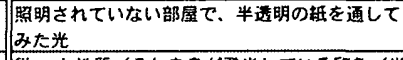 \\
\hline & 面発光 & 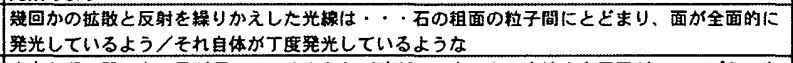 & 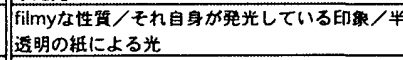 \\
\hline & 閻の中の戟き & 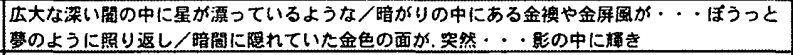 & 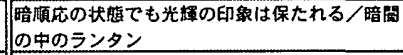 \\
\hline & 焱 & 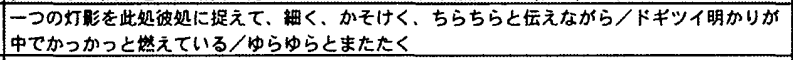 & 帘 \\
\hline \multirow{2}{*}{ 妁熱 } & 内部からの光 & 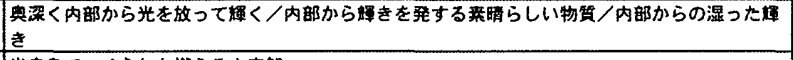 & ものものの内部まて色が㧁がった感じ \\
\hline & はっきりとした输郭 & 光自身でつくられた妷える十字架 & 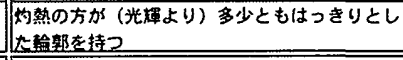 \\
\hline \multirow{3}{*}{$\begin{array}{c}\text { 表面色 } \\
+ \\
\text { ライティンク }\end{array}$} & 色光 & 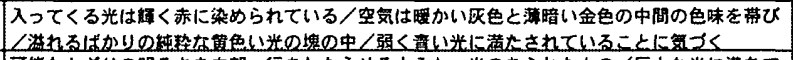 & \\
\hline & 光に満ちた & 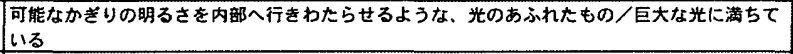 & \\
\hline & 薄暗さ & 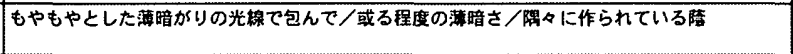 & \\
\hline \multirow{2}{*}{$\begin{array}{c}\text { 表面色 } \\
+ \\
\text { イルミネーション }\end{array}$} & 影 & 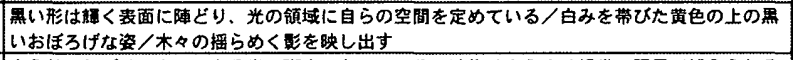 & \\
\hline & 光のスポット & 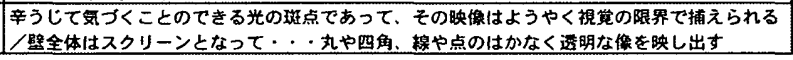 & \\
\hline
\end{tabular}

表 4. フェノメナルな光の分類 : 写真

\begin{tabular}{|c|c|c|c|}
\hline モード & 数 & 代表例 (ページ、設計者、建物名) & 説明 \\
\hline 面色 & 123 & 358 Saarinen:North Christian Church & オルガン背後の面がテクスチャが暖昧で距誰感が失われており、面色への移行過程と見なせる。 \\
\hline 空間色 & 25 & 326 Kahn: Indian Institue & 奥の閣の部分及び採光部に近い部分などが螌んでいるように見える。 \\
\hline 透明面色 & 22 & 405 Skidmore:Chapel & オレンジ色の透明色カラスを通して背景の山並が写っている。 \\
\hline 透明表面色 & 169 & 143 Le Corbusier:Cite de Refuge & 半透明のガラスプロックのテクスチャが良く見えている。 \\
\hline 鏡映色 & 26 & 213 Siza:Galcian Center & 本に壁の絵などが映り込んでいる \\
\hline 光沢 & 33 & 202 Legorreta:House in SC & 水面の光沢が映っている \\
\hline 光胱 & 82 & 18 Le Corbusier:la-Tourette & 礼洋堂上のトップライト部が面色から光阽の見えを呈している \\
\hline 灼熱 & 19 & 201 Ando: Church of the Light & 正面十字架の部分は形がはっきりとし、かつ内部から光が㜋れている感じ \\
\hline 表面色+照明 & 18 & 129 Gaudi:la Colonia Guell & 黄色のステンドクランスによって色のついた光が柱手前一带に当たっている \\
\hline 表面色+照射 & 57 & 283 Johnson:Sculpture Gallery & 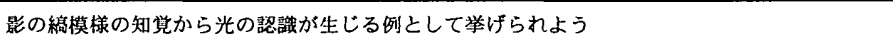 \\
\hline
\end{tabular}


までは不可能であった。ただしどちらも現代の建築においては光の 効果として数多く指摘される例であり、今後調查対象を広げた検討 が必要であろう。

\section{4 フェノメナルな光の分類 : 写真}

本論文の主要な目的は、フェノメナルな光を言葉上で抽出・分類す ることにあるが、より多くの例を網羅するために、建築における光 の写真を集めた文献 (4)を取り上げた。フェノメナルな光と捉えられ る対象が、上述の見えのモードの゙どれか一つに分類できることの確 認を行うこ之が目的である。

写真の場合は、特に面色一光輝、面色一透明表面色注 16) などの見 極めが難しく、単一のモードへ明確に分類できないことが多いが、実 際の建築空間においても複数のモードが視野内に同時に存在するこ とは一般的であることから特に問題はないと考えた。以上の結果、 362 枚中 326 枚の写真を表面色以外の見えのモードの分類に割り当て ることができた。表 4 に代表例を示す。

\section{5 見えのモードの分類から漏れるフェノメナルな光に関して}

2.2 に示した手順により文献より抽出された記述、及び「光の空間」 の写真の中に、表面色にしか分類ができないものが含まれていた。具 体的には、色のついた照明光（例：夕日）が空間に広がっている場 合の見え: 木漏れ日などの影が対象に掛かっている場合の見え、ス ポット照明が対象に照射されている場合の見えなどが挙げられる。 いずれも建築における光の現象としては頻繁に取り上げられるもの であり、今回の文献中においても例は多い。

従ってフェノメナルな光として無視できないものであり、本論文で は、表面色に《照明》の条件が重なった場合に生じる現象として、 フェノメナルな光に包含する注 17)。さらに《照明》は、空間全体に 広がる《ライティング》と、ある対象を照射する《イルミネーショ ン》に分割可能として、以下のように定義する。

2.5 .1 表面色+《ライティング》

色のついた照明光の認識は、表面色の上に認知されるという点で、 透明面色としての認識に非常に近い。つまり照明に色がついている 場合と、同じ色のフィルターを通して空間を見た場合の感じは非常 に似ており、カッツも両者の区別が難しい場合があることを指摘し ている。しかしながら、タ日の色を認識している場合に、透明面色 を見ていると認識することはなく、また人間は基本的には視覚対象 から照明の効果を分けて認識ことが可能であることから、両者を現 象としては区別して捉えた方がよい。

このような光は空間全体に広がるものであるが、ここではカッツの 用語「a lighting of empty space」注 18）を参考に、このフェノメナルな 光を「表面色 +《ライティング》」として位置付け、以下のように定 義する : 空間に広がる照明が、表面色の見えなどから判断して、色 および量において《普通》注 19) でないと認識される場合、「表面色＋ 《ライティング》」としてのフェノメナルな光の知覚が生じる。

○「LJA」：伏見稲荷大社の「透過してくる光は鮮やかな薄紅色に 彩られ、空気を滤過して床石や服をこうした繊細で滑らかな感覚的 色彩で色づける」を例に挙げることができる。

•「建築行脚」：サン・ヴィターレ聖堂の「過飽和状態になるまで に圧倒的な量の溢れでてしまう光の海」「強度そのもの」「光の渦
が・・・金色に染まっている」などは色、量ともに《普通》の状態 を超えた照明の認識と言えよう。

2.5 .2 表面色+《イルミネーション》

木漏れ日などの影の存在も光の知覚には非常に重要な要素である。 影が見えている場合、コントラストが強ければ光沢が生じるが、大 抵は表面色の上に重なって現れる。表面色上の暗い（or 黒い）部分 ・が、影なのか対象の明度が低いだけなのかを判断するメカニズムの 解明はまだ完全にはなされていないが、少なくとも現象的には影の 知覚は確かに起こるものであり、「表面色十《イルミネーション》」と して、フェノメナルな光の分類に含めるべきだと思われる。なおス ポット照明などによるフェノメナルな光の認識も、影の相対概念と して「表面色+《イルミネーション》」に含める。

•「LJA」: 京都詩仙堂の庭の上の影に関する「椿の木よりも影に 集中するようになって、美しい楕円の網は真っ白い紙の上の黒い墨 絵のように、うっすらと波打つ白い地上に漂っている」、安藤忠雄の コンクリートの外壁に関する「このそっけない壁はどんなに小さく てわずかな影をも拡大して、背景の白に黒い線と点を強調し、穏や かな静けさの中にさらさらという影の動きをみせる」など、フェノ メナルな光としての影の記述が数多く見られる。

\subsection{3 その他}

「光の空間」におけるミース・ファン・デル・ローエの Lake Shore Drive Apartment やフィリップ・ジョンソンの Glass House は、写真で 判断する上では、それぞれ光沢部分や鏡映色部分が含まれていたり するため、表面色以外の見えのモードへ割り振ることは可能である。 しかしながら全体としては表面色が基調となっている。ミースの光 について「光の空間」の挿入文に書かれているように、「世界に満ち 満ちる光が、建築の外部も内部も変わらず一定の密度で満たしてい く」「官能的な材料の用法からきわめて即物的な手法へと移り変わっ ている」とすると、これらはむしろ《普通》の照明下での表面色を 積極的に出したものであり、フェノメナルな光とは対極に位置付け られるものである。このような等質空間の光とフェノメナルな光と の関係の詳細な検討は今後の課題として本論文では保留するが、 フェノメナルな光の限界領域を指示するものとしての可能性を指摘 しておきたい。

\section{3、まとめ}

以上から、建築における知覚可能な光の現象として、フェノメナル な光を図 5 に示すように分類し、その範囲を示した注 20)。これによ り今回の文献に現れた光の現象はほほ全てを分類することができて おり、仮に今後新たな光の現象が出てきたとしても、この分類を下 敷きに変更を加えていくことができるであろう。特にカッツの分類 は決して網羅的であることを保証したものではなく、今後光の定量 化を行う上でさらなる紐分類が必要になる可能性は残っている。

今後は知覚心理学の知見などを参考に工学的な条件を検討してい く予定だが、現状では「光源色」(特に光輝や面色に関わってこよう） 一「物体色」の現れや、「光沢」の表出などに関しては一定の知見が 得られているといって良い。ただしいずれも定説と呼べるような最 終解は得られていないため、既往の知見から徐々に工学的な必要条 件を与えていくことになろう。また《照明》の知覚原理を明らかに することは非常に重要な課題と考えられるが、本論文では《照明》に 
関しては 2 分類したのみであり、実際に工学的条件を考察していく 上では、あらかじめさらなる対象の整理が必要となろう。また《ラ イティング》《イルミネーション》の知覚に関しては、知覚心理学の 分野における今後の更なる研究の進展に待つところが大きいように 思われる。

以上、本論文においてフェノメナルな光を分類する枠組みを呈示し てきたが、今後建築の光をより定量的かつ工学的に捉えていく上で。 の第一歩として、一定の意義を持つものと考える。

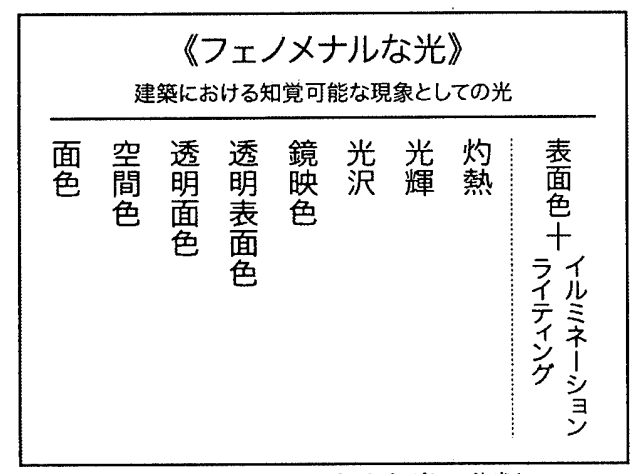

図 5 フェノメナルな光の分類

謝辞

本論文をまとめるにあたり、小川裕樹君、有坂美垔さん、税乺典久君 （当時、東京理科大学学生）の協力を得ました。記して謝意を表します。

注

1）本論文における「工学的」とは、ある対象（この場合は建策における光の 現象）を得るために、計画・設計・製作の段階に基礎的科学の知見を応用 していくことを意味し、言い換えれば現象の光に対しても因果律を想定し て、目的変数 (現象の光) - 説明変数 (要因) の関係性を探ることを指す。 説明変数は必ずしも全てが量的変数である必要性はない。

2)この知覚可能な光の現象という表現に対して、光を純粋な伝達媒体と捉え てそのもの自体は不可視であるとする立場からの反論もあるかと思われる が、建築の言説においては光という言葉で語られる、光の作用の結果とし ての現象が存在してきたことは確かであり、そのような現象を本論文では 研究対象とする。

3）ただし OSAなどの分類は、より因果律を想定した分析に馿染むものであ り、今後実際に各モードの現れを工学的に条件づけようとする際の参考に なる。またカッツの分類は決して網羅的なものではなく、また各モードが 完全に独立かつ同等なわけではないことに注意が必要である。

4)「The world of colour」は原書はドイツ語であるが、本論文では便宜上英語 訳を参照した。

5）例えば、芦原の著作「隠れた秩序」（参考文献 5) の中では、日本建築に おける「陰」の重要性が、「陰影礼譲」を引合いに説明されている。

6)「建築行脚」シリーズを取り上げた理由は他に、(1)「Light in Japanese Architecture」には、安藤忠雄、伊東豊雄、險研吾、槙文彦、原広司、黒川 紀章、長谷川冕子、妹島和世など、現在の日本を代表する建筑家の建物が 多く取り上げられているが、磯崎新の建築にはあえて触れられていない。 そのため、磯崎新の著作を選択することでより網羅的に光の現象を収集す ることを狙ったため、(2)光の現象を言葉で表現したものとして数は少ない が非常に優れた文章が含まれていると判断されるため、である。

7)つまり後述の表面色の見えを呈するものはこの段階で省いた。

8) 明暗に対する印象は、空間内の光量などから決定されると考えられるが、 一般的な範囲内での空間の明暗の判断は、後述の《普通》の照明状態に当 たり、本論文では光の現象とは見なさない。

9）本論文中で日本語で記述する際には、より直訳に近くなるよう訳し直した 䈯所もある。

10）力ッツの定義に戦密に従うならば、本来はモードそのものとモード間の 移行過程（カッツは transformation という言葉を用いて言及している）は 区別すべきであろうが、建築における光の現象としてはこの移行過程がよ り重要であると考えられ、本論文ではカッツの定義を各モードの典型例の 記述と見なし、そのモードへの移行過程をも包含した分類とする。

11）ただしカッツは表面色 (surface color) は、必ずしも 'object color = belonging to the object' と同義ではないと強調しているように、笄密に言えばJIS Z8105:2000 の物体色の定義「対象物体に属しているように知賞される色」 とは若干異なる概念である。ただしカッツの表面色の定義は、JIS Z8105:2000の表面色の定義「(対象物の) 表面から昖散的に反射又は放射 しているように知覚される色」とも、発光知覚色は含まれない点で異な る。むしろ改定前の JIS の表面色の定義「表面から㹡散的に反射している ように知覚される色」に近く、その場合岡鴄が文献 11) で説明している ように「物体色」=「表面色」＝「反射物体的な見えを呈する色」となる
う。明由川らは物体としての色の見えがどの定義に当てはなるのか、䈔密 には規定していないが、カッツの表面色とほぼ一致すると見なしても便宜 上問題はないだろう。

12）この用語はコーリン・ロウの「フェノメナル（虚の）な透明性」から借 用したが、ロウの場合は構造としての透明性が問題になっているため、定 義は異なってくる。ただし、将来的に、その対概念である「リテラル（実

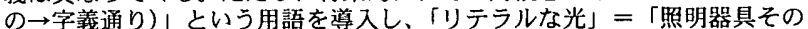
もの」と定義すれば、㹨義のフェノメナルな光を「もの（表面色）でもな く、リテラルな光でもない中間状態」と別位相において位置付けることが 可能となろう。建築的課題としては、この照明器具そのものを除いた狭義 のフェノメナルの定義の方が、より興味深いものとなるかもしれない。

13）ある開口を通して表面色を見ると、その部分が周りの文脈から切り離さ れて、面色が現れやすくなる。このような色を「開口色」とも呼ぶ。

14）カッツははっきりと空間色を知覚するには、背景の物体 (object)が「知 覚」されなければいけないと述べているが、"The World of Colour" の英語訳 では、「discern, perceive, see]+[objects] という動詞が当てられている。背景 の物質の認識がどの程度のレベルであれば良いのか（その存在が意識され クば良いのか、あるいは視覚的にはつきりと見えなければならないのか） 不明暸な点が残っているが、谷崎や磯崎の「蘭」は、構造体に囲ま机た屋 内でしか存在しない現象であり、そこでは磯崎が言及しているように、背 後にひそんでいる物体の存在が常に感知 (perceive) されている。従って本 論文ではこの「聞」を空間色に分類するのが妥当であると考える。ただし 将来的には実空間での体験を基に、より細分化する可能性は残っている。

15）あくまで各モードの参考のため、「LJ」に出てきた建築空間を別に撮影 した写真を示す。必ずしも文献中の現象と殿密に一致するわけではない。

16）例えば空を背景にしたガラス面の場合、ガラス面が細かく分節されてい る場合は透明表面色、ガラス面一林が大きく見える場合は面色への分類が 妥当と言えようが、写真上で明確に区別することは困難である。

17）なお「表面色十照明」に対応する各文献内の記述（拔粋）及び記述の数 は表 2 の最後に、類似性に着目して記述をさらに細分類した結果は表 3 の 最後に、文献 (4) における写真の例は表4の最後に、それぞれ示した。

18) カッツは「empty space」(何もない空間) に広がる照明そのものを人間は 確かに認識しているとしており、そのような照明に「a lighting of empty space」という用語を当てている。ここでの照明は同じく空間に広がる照 明の認識であるため、この用法を借用した。なおこの lighting の認識に関 しては、照明認識視空間との関倸が重要であろう。

19）《普通》(カッツの用語では normal) の定義が瞹昧であるが、カッツによれ ば、対象物の本物の色を見ることができる照明条件で、薄需りの日の昼の

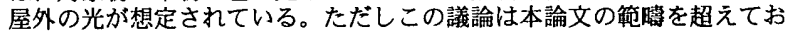
り、ここでは《普通》という言葉を用いた定義のみの提案に留める。

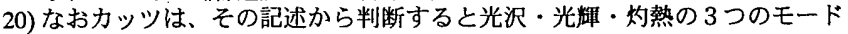
を光 (light) と捉えていたと考えられるが、本論文でのフエノメナルな光は 「建築における言説の中で光として报われてきた現象」であり、カッツ自 身が光（light）という言葉で指し示した対象とはその範围が異なる。

参考文献

1) Katz, D.(1935) The World of Colour. London: Kegan Paul, Trench, Trubner, translated by $\mathrm{R}$ B Macleod and C W Fox.

2) Gilchrist, A.et al.(1999) An Anchoring Theory of Lightnss Perception, Psychological Review, 106-4, pp795-834

3) J.W.V. ゲーテ (2000) 色彩論, 高橋 義人他訳, 工作舎

4) Plummer, H.(1995) Light in Japanese Architecture, a+u, Tokyo.

5) 芦原義信 : 隠れた秩序、中公文庫、1989

6) 明田川洋、鈴木信宏 : 光の在り方による建築空間の構造、日本建築学会学 術講演梗概集＜計画系＞、pp2715、1983.9

7) 池田正之、李東植、関口威人、宮本浩典 : 建築における光の役割と利用、日 本建築学会大会学術講演梗概集 E-1、pp.913、1995.8

8) 池田光男、福村史麻、松澤伸子、石田泰一郎：局所照明認識閵に対する周 辺視覚情報の影響、光学、23-1、pp42-50、1994

9) 磯崎新、穕山紀信ほか：建築行脚シリーズ（No.1〜 No.12）、六耀社

10) 今岡敦典、吉澤望、平手小太郎、安岡正人：光の認識の体系化に関する研 究 (その 1 ) 光の分類、日本建築学会大会学術講演梗概集 D-1、pp.485、 1995.08

11) 岡嶋克典 : 色の見えのモード、日本色彩学会誌、24-1、pp51-57、2001

12) 川崎雅史、堀秀行、佐佐木網 : 日本の伝統的空間に現れる陰影の意匠性に 関する研究、士木学会論文集、No.458/ IV -18、pp.121-127、1993.1

13) 小泉隆、鉿木信宏 : 建勧空間における空間秩序的太陽光効果とそれらの要 因、日本建築学会計画系論文集、第 516 号、153-160、1999.2

14）小泉隆、鈴木信宏 : 太陽入射光と介在物の異なる透過光障子面の光現象か 与える質的イメージとその構造、日本建築学会計画系論文集、第 536 号、 157、2000.10

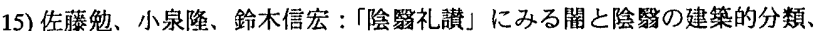
日本建築学会大会学術梗概集 F、pp1053、1990.10

16) 谷崎潤一郎 : 陰敏礼謮、中公文庫、1975

17）田山真理、船越徽、積田洋：建築空間における光の効果の研究：その 2 物 理量分析・相関分析、日本建築学会大会学術講演梗概集 E、pp759、1991.9

18) 二川幸夫、三宅理一：光の空間 1 \& 2、GA、1994

19) 古藤武彦、小泉隆、鈴木信宏 :「建策 : 光の詩学」にみる自然光のイメ一 シととそ作り出し方、日本建築学会大会学術梗概集 E-1、pp671、1996.9

（2004年 2 月 13 日原稿受理，2004年 7 月 7 日採用決定） 